\title{
REGIONAL PATTERN AND CHARACTERISTICS OF ESSENTIAL ELEMENTS IN SEVERAL MEDICINAL PLANTS USING SPECTROMETRIC METHODS COMBINED WITH MULTIVARIATE STATISTICAL APPROACHES
}

\author{
SIMONA CODRUȚA AURORA COBZAC ${ }^{a, b}$, TIBERIU FRENȚIU ${ }^{a, b}$, \\ BILIJANA BALABANOVAc, NATALJA MARKOVA RUZDIK ${ }^{\mathrm{d}}$, \\ DORINA CASONI ${ }^{a, b^{*}}$
}

\begin{abstract}
The aim of this study was to provide a regional pattern and characteristics of essential elements in several medicinal plants from North Macedonia and Romania. The content of $\mathrm{Ca}, \mathrm{Mg}, \mathrm{Al}, \mathrm{Fe}, \mathrm{Cu}, \mathrm{Ba}$ and $\mathrm{Zn}$ was determined by ICP-OES while $\mathrm{Na}$ and $\mathrm{K}$ by FAES in some medicinal plants belonging to sixteen families. Similar profiles of elements with a high content of $\mathrm{Ca}, \mathrm{Mg}$ and $\mathrm{K}$ were observed. Peppermint and blackberry from both countries showed extreme content in $\mathrm{Al}$ and $\mathrm{Fe}$. A symmetric distribution for $\mathrm{K}$, $\mathrm{Ca}$ and $\mathrm{Zn}$ and an asymmetric one for $\mathrm{Na}, \mathrm{Al}, \mathrm{Fe}$ and $\mathrm{Ba}$ were found in medicinal plants from both countries. Potassium, $\mathrm{Ca}, \mathrm{Mg}, \mathrm{Al}$ and $\mathrm{Fe}$ could be considered as markers for growing area. Principal Component Analysis highlighted that the variability of elements content was described by four factors $(83.4 \%)$ in North Macedonia and three factors $(70.0 \%)$ in Romania. The first factor could explain the influence of soil nature upon variability of elemental composition, calcareous in North Macedonia (Mg and Ca - 29.4\% variance) and a rich one in hydroxides in Romania (Al and $\mathrm{Fe}-33.1 \%$ variance).
\end{abstract}

Keywords: essential element, medicinal plant, inductively coupled plasma optical emission spectrometry, flame atomic emission spectrometry, Principal Component Analysis, two-way joining Cluster Analysis

a Babeş-Bolyai University, Faculty of Chemistry and Chemical Engineering, 11 Arany Janos str., RO-400028, Cluj-Napoca, Romania

b Research Center for Advanced Chemical Analysis, Instrumentation and Chemometrics, Arany Janos 11, 400028 Cluj-Napoca, Romania

c Department of Soil Chemistry and Hydrology, Faculty of Agriculture, Goce Delcev University, Krste Misirkov 10-A, 2000, Stip, Republic of North Macedonia

d Department of Plant Production, Faculty of Agriculture, Goce Delcev University, Krste Misirkov 10-A, 2000, Stip, Republic of North Macedonia

*Corresponding author: dorina.casoni@ubbcluj.ro 


\section{INTRODUCTION}

The medicinal plants consumed preferable as teas or tinctures, have a long and rich history regarding their usage as therapeutics. The World Health Organization (WHO) estimated that $80 \%$ of the current population use medicinal plants for some aspect of primary healthcare [1]. It is thought that some medicinal plants contain elements of vital importance for human metabolism, disease prevention and healing [2]. Besides their use for treatment of diseases, the medicinal plants are also used as dietary supplements once they are found to be rich in one or more elements. So, their chemical composition in terms of nutrients, minerals, vitamins, and essential antioxidants need to be permanently monitored. Elemental content can vary in a wide range, depending on factors such as soil geochemical characteristics, the climate conditions, irrigation water, use of fertilizers and the ability of each plant species to selectively accumulate some of them [3,4]. Metals, categorized as macro (primary) or micro (trace) elements play an essential role in the body some of them being crucial for many body functions. Essential elements such as sodium, potassium, calcium, magnesium, phosphorus, iron, zinc, copper, manganese and non-essential elements such as aluminium, barium, cadmium and lead were found in various medicinal plants [5]. Macroelements such as potassium, calcium, magnesium, phosphorus, and sodium are contained in concentration greater than $100 \mathrm{mg} \mathrm{kg}^{-1}$ while trace elements including iron, zinc, manganese, molybdenum, selenium, chromium, copper, cobalt and sulphur are usually contained in concentration less than $100 \mathrm{mg} \mathrm{kg}^{-1}$ [6].

The determination of elements in medicinal plants and their impact on human health is of great importance. Besides, their essential importance in the living system, several elements can be toxic when the concentrations exceed those necessary for metabolic functions [7, 8]. The level of elements permitted by the WHO should not endanger the health of consumers $[9,10]$. Inductively coupled plasma-optical emission spectrometry (ICP-OES), atomic absorption spectrometry (AAS) and neutron activation analysis (NAA) methods have been used for the determination of elements concentration in medicinal plants and plant based multivitamin preparations [11, 12].

The aim of this paper was to provide a regional pattern and characteristics of essential elements in several medicinal plants from Romania and North Macedonia using spectrometric methods combined with multivariate statistical approaches. Romania and North Macedonia possesses a great vegetal genetic diversity, as for example Romania cover $30 \%$ of the European flora with a number of 3700 plant taxa, from which 283 were identified as medicinal plants $[13,14]$. However, according to our best knowledge there are 
few studies related to determination of essential elements in medicinal plants from two countries. From this point of view, the study has relevance and is of general interest for both producers and consumers. The content of $\mathrm{Ca}$, $\mathrm{Mg}, \mathrm{Cu}, \mathrm{Fe}, \mathrm{Zn}, \mathrm{Al}$ and $\mathrm{Ba}$ were determined by ICP-OES, while $\mathrm{Na}$ and $\mathrm{K}$ content was determined by flame atomic emission spectrometry (FAES) in different parts (root, leaves, flowers, fruits) of different variety of medicinal plants originating from two countries. Principal Component Analysis (PCA) and two-way joining Cluster Analysis were used to describe variability of chemical composition of the medicinal plants under study and recognize the parameters significantly different. It is expected that the elemental composition to be different depending of variety and region of provenience due to soil and climatic conditions influence. So far a similar complex approach has not been performed on medicinal plants from Romania and North Macedonia.

\section{RESULTS AND DISCUSSION}

\section{Patterns of essential elements in medicinal plants}

Results obtained in the determination of elements concentration in medicinal plants originated from North Macedonia and Romania are given in Supplementary material (Table S1). The sample code of medicinal plants is presented in the experimental part, Table 5.

The content of $\mathrm{Co}, \mathrm{Cr}, \mathrm{Cd}, \mathrm{Ag}, \mathrm{Mn}, \mathrm{Ni}, \mathrm{Sr}, \mathrm{Pb}$ were below LOD in ICPOES. The elemental profiles of the selected medicinal plants are presented in Figure 1, while summary statistics is provided in Table 1.

Figure 1 reveal that the selected medicinal plants from both countries show similar profiles but different content of macroelements and microelements depending of variety and the nature of the plant sample. Therefore, the analysed plants are mainly characterized by high content of $\mathrm{Ca}, \mathrm{K}$ and $\mathrm{Mg}$. Interestingly is the high content of $\mathrm{Al}$ and $\mathrm{Fe}$ for Peppermint $(\mathrm{Pe})$ and Blackberry (BI) from both countries.

Data in Table 1 shows either asymetric or symetric distribution of elements content around the mean. 

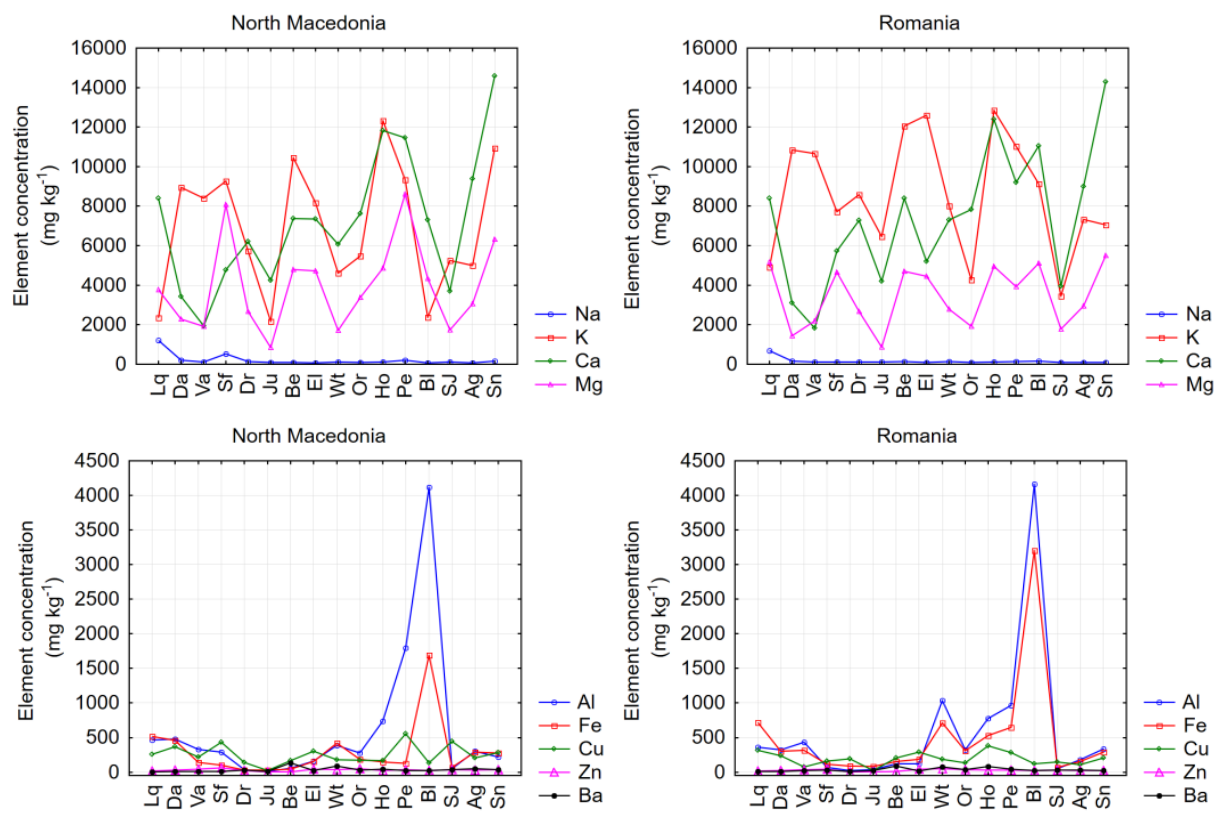

Figure 1. Profiles of the elemental content in the analysed medicinal plants from North Macedonia and Romania. The sample code of medicinal plants is presented in the experimental part, Table 5.

A positive Skewness and leptokurtic distribution was observed for $\mathrm{Na}$, $\mathrm{Al}, \mathrm{Fe}$ and $\mathrm{Ba}$ in the samples from both countries. These distributions are consistent with extreme values observed for $\mathrm{Na}$ in Liquorice (Lq), $\mathrm{Al}$ and $\mathrm{Fe}$ in Blackberry (BI) and $\mathrm{Ba}$ in Wild thyme (Wt) and Bean (Be) samples (Figure 2). An symetric repartition with platikurtic distribution could be observed for K, $\mathrm{Ca}$ and $\mathrm{Zn}$ in samples from both countries while $\mathrm{Mg}$ and $\mathrm{Cu}$ show a symetric distribution only for plants of Romanian provenience.

Therefore, the median and the mean values for asymetric and symetric distribution, respectively, were considered for an overall comparison of metals content in analysed plants. In case of plants from North Macedonia, the following decreasing order for macroelements $\mathrm{Ca}>\mathrm{K}>\mathrm{Mg}>\mathrm{Na}$, for microelements $\mathrm{Al}>\mathrm{Cu}>\mathrm{Fe}>\mathrm{Zn} \approx \mathrm{Ba}$ respectively, was observed. In case on Romanian samples the following order was observed $\mathrm{K}>\mathrm{Ca}>\mathrm{Mg}>\mathrm{Na}$ and $\mathrm{Al} \approx \mathrm{Fe}>\mathrm{Cu}>\mathrm{Zn} \approx \mathrm{Ba}$. These differences could be explained by influence of the soil composition on metals bioavailability in medicinal plants. 
REGIONAL PATTERN AND CHARACTERISTICS OF ESSENTIAL ELEMENTS ...

Table 1. Summary statistics for elements content $\left(\mathrm{mg} \mathrm{kg}^{-1}\right)$ in medicinal plants samples from North Macedonia $\left({ }^{1}\right)$ and Romania $\left({ }^{2}\right)$, described in the experimental part, Table 5.

\begin{tabular}{|l|r|r|r|r|r|r|r|}
\hline Element & \multicolumn{1}{|c|}{ Min } & \multicolumn{1}{c|}{ Max } & \multicolumn{1}{c|}{ Mean } & \multicolumn{1}{c|}{ Median } & STDEV & SKEW & KURT \\
\hline $\mathrm{Na}^{1}$ & 61.49 & 1443.92 & 253.44 & 108.70 & 342.34 & 2.63 & 6.80 \\
\hline $\mathrm{Na}^{2}$ & 75.82 & 681.06 & 145.22 & 105.64 & 136.95 & 3.83 & 15.27 \\
\hline $\mathrm{K}^{1}$ & 1804.47 & 12334.69 & 6818.36 & 5731.00 & 3178.30 & 0.05 & -1.12 \\
\hline $\mathrm{K}^{2}$ & 3440.42 & 13648.22 & 8702.09 & 8417.91 & 2968.28 & 0.00 & -0.86 \\
\hline $\mathrm{Mg}^{1}$ & 828.02 & 8594.53 & 3715.03 & 3419.53 & 1896.92 & 0.67 & 0.41 \\
\hline $\mathrm{Mg}^{2}$ & 872.30 & 5504.87 & 3467.38 & 3369.00 & 1458.04 & -0.23 & -1.44 \\
\hline $\mathrm{Al}^{1}$ & 9.29 & 4118.28 & 528.07 & 277.09 & 890.62 & 3.45 & 12.96 \\
\hline $\mathrm{Al}^{2}$ & 21.64 & 4165.67 & 603.73 & 321.61 & 961.04 & 3.25 & 11.65 \\
\hline $\mathrm{Ca}^{1}$ & 1941.08 & 16100.34 & 7606.94 & 7370.84 & 3387.57 & 0.63 & 0.51 \\
\hline $\mathrm{Ca}^{2}$ & 1812.82 & 14285.71 & 7547.95 & 7820.90 & 3221.15 & 0.19 & -0.21 \\
\hline $\mathrm{Fe}^{1}$ & 28.34 & 1689.66 & 288.34 & 154.03 & 362.06 & 3.02 & 10.56 \\
\hline $\mathrm{Fe}^{2}$ & 68.03 & 3203.59 & 500.14 & 305.08 & 716.79 & 3.41 & 12.72 \\
\hline $\mathrm{Cu}^{1}$ & 23.91 & 584.18 & 267.33 & 222.58 & 137.99 & 0.82 & 0.42 \\
\hline $\mathrm{Cu}^{2}$ & 23.98 & 380.97 & 196.12 & 189.16 & 92.48 & 0.23 & -0.33 \\
\hline $\mathrm{Zn}^{1}$ & 4.67 & 64.03 & 33.00 & 32.08 & 15.01 & 0.01 & -0.31 \\
\hline $\mathrm{Zn}^{2}$ & 2.07 & 47.55 & 25.94 & 25.63 & 12.38 & -0.39 & -0.26 \\
\hline $\mathrm{Ba}^{1}$ & 2.85 & 134.45 & 33.14 & 21.42 & 32.12 & 1.93 & 3.90 \\
\hline $\mathrm{Ba}^{2}$ & 9.45 & 90.39 & 34.46 & 27.37 & 24.47 & 1.33 & 0.60 \\
\hline
\end{tabular}
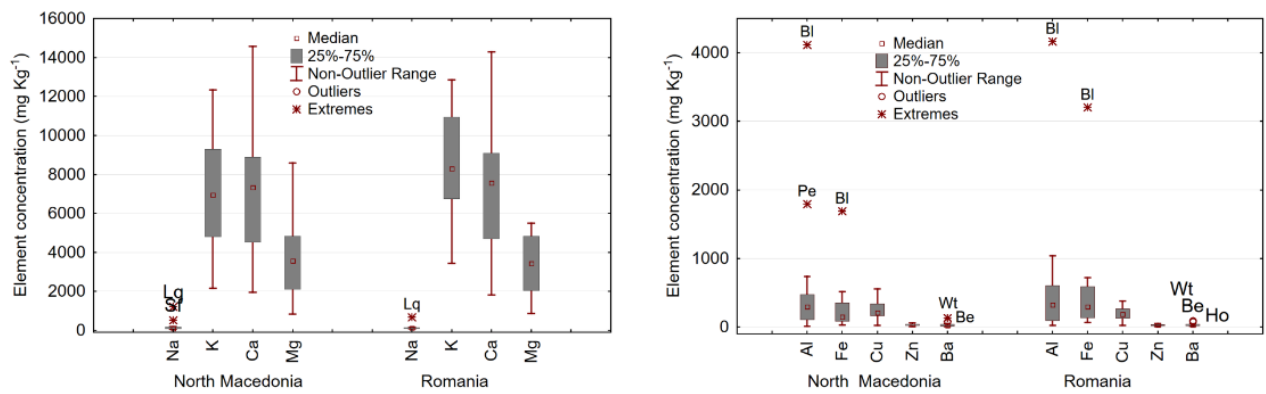

Figure 2. Box and whiskers plot for content of elements in medicinal plant samples. The sample code of medicinal plants is presented in the experimental part, Table 5. 


\section{Statistical evaluation of analysed medicinal plants}

The correlations between the content of elements found in medicinal plants from North Macedonia and Romania are presented in Table 2.

Table 2. Correlations between content of elements found in medicinal plants from North Macedonia $\left({ }^{1}\right)$ and Romania $\left({ }^{2}\right)$. Bold values show significant correlations $(p<0.05)$.

\begin{tabular}{|c|c|c|c|c|c|c|c|c|c|}
\hline Element & $\mathrm{Na}^{1}$ & $\mathrm{~K}^{1}$ & $\mathrm{Ca}^{1}$ & $\mathbf{M g}{ }^{1}$ & $\mathbf{A l}^{1}$ & $\mathrm{Fe}^{1}$ & $\mathrm{Cu}^{1}$ & $\mathrm{Zn}^{1}$ & $\mathrm{Ba}^{1}$ \\
\hline $\mathrm{Na}^{2}$ & 0.92 & -0.32 & 0.02 & 0.35 & -0.13 & 0.00 & 0.35 & -0.08 & -0.27 \\
\hline $\mathbf{K}^{2}$ & -0.37 & 0.62 & 0.21 & 0.34 & -0.29 & -0.36 & 0.49 & 0.26 & 0.41 \\
\hline $\mathrm{Ca}^{2}$ & 0.07 & 0.13 & 0.92 & 0.66 & 0.12 & 0.11 & 0.53 & 0.02 & 0.26 \\
\hline $\mathbf{M g}^{2}$ & -0.02 & 0.30 & 0.50 & 0.72 & 0.11 & 0.10 & 0.46 & 0.24 & 0.13 \\
\hline$A \mathbf{l}^{2}$ & 0.07 & 0.18 & 0.37 & 0.36 & 0.96 & 0.95 & 0.01 & 0.03 & -0.06 \\
\hline $\mathrm{Fe}^{2}$ & 0.25 & -0.01 & 0.31 & 0.31 & 0.92 & 0.95 & -0.07 & 0.02 & -0.17 \\
\hline $\mathrm{Cu}^{2}$ & 0.01 & 0.02 & -0.13 & 0.13 & -0.16 & -0.17 & 0.35 & 0.39 & -0.16 \\
\hline $\mathrm{Zn}^{2}$ & -0.29 & -0.13 & -0.18 & -0.01 & -0.17 & -0.21 & 0.01 & 0.74 & -0.24 \\
\hline $\mathrm{Ba}^{2}$ & -0.21 & 0.23 & 0.25 & 0.16 & -0.06 & -0.10 & 0.06 & 0.02 & 0.82 \\
\hline
\end{tabular}

Statistical significant correlations were observed for $\mathrm{Na}, \mathrm{Ca}, \mathrm{Al}, \mathrm{Fe}$ and $\mathrm{Ba}$. For $\mathrm{Mg}, \mathrm{Cu}$ and $\mathrm{Zn}$ (elements with a symmetric distribution in the analysed plants) a lower correlation was observed.

The two-way joining Cluster Analysis and PCA methods were applied to better reveal the variability of profile for content of elements in medicinal plants under study. Heat maps (Figure 3 ) were depicted by choosing a colour graduation starting with the green tone for the low values below the mean content, up to the red tones above these values. Based on similarity pattern approaches, in both countries the concentration of elements depends on the variety of medicinal plants. Significant differences between medicinal plants from North Macedonia and Romania were observed especially for $\mathrm{K}, \mathrm{Ca}, \mathrm{Mg}$, $\mathrm{Al}$ and $\mathrm{Fe}$ content which can be considered as important constituents for originating growth area of the plants. Also, in both countries Stinging nettle $(\mathrm{Sn})$, Horsetail $(\mathrm{Ho})$, Peppermint $(\mathrm{Pe})$, Bean $(\mathrm{Be})$ and Elderberry $(\mathrm{El})$ have a high content in $\mathrm{Ca}$ and $\mathrm{Mg}$ while Blackberry $(\mathrm{BI})$ is characterized by high content in Al. Plants as Elderberry (El), Dandelion (Da), Valerian (Va) and Blackberry $(\mathrm{BI})$ from Romania were observed to have a high content in $\mathrm{K}$ comparative with content in samples from North Macedonia. 

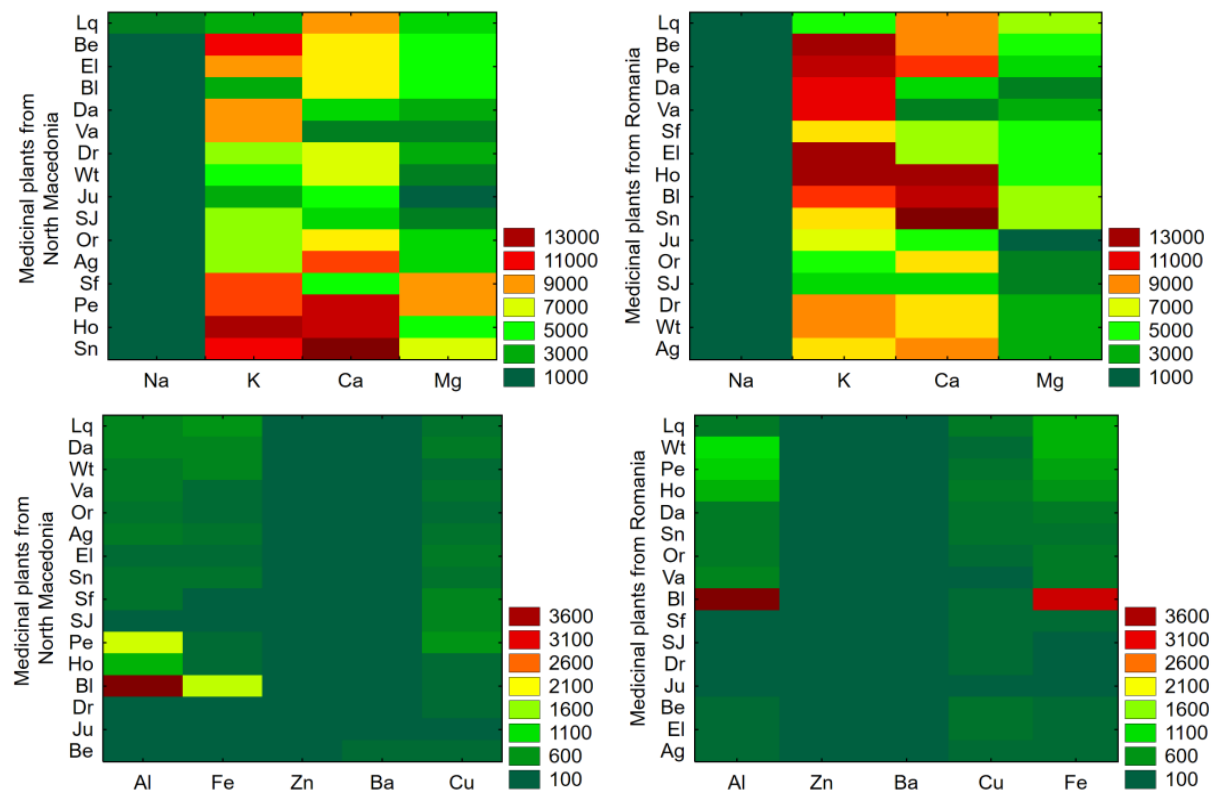

Figure 3. Two-way joining heat map revealing the variation of macroelements and microelements content $\left(\mathrm{mg} \mathrm{kg}^{-1}\right)$ in medicinal plants from North Macedonia and Romania. The sample code of medicinal plants is presented in the experimental part, Table 5.

Based on the heat maps from the auto-scaled values of determinations (Figure 4), some markers were revealed as differentiating the elemental profile of some of the analysed medicinal plants from two countries. Among the analysed elements potassium differentiate Stinging nettle (Sn) and Elderberry (EI), cupper differentiate Horsetail (Ho), St.John's wort (SJ) and Sweet fennel (Sf) while magnesium is an important element that differentiate the elemental profile of Liquorice (Lq), Blackberry (BI), Bean (Be), Elderberry (EI) and Horsetail (Ho) from North Macedonia and Romania.

The PCA analysis (Table 3 ) shows that variability of the characteristics in the medicinal plants under study from North Macedonia is described in proportion of $83.4 \%$ by four factors with a strong contribution (loadings $>0.700)$ for $\mathrm{Mg}, \mathrm{Ca}, \mathrm{Al}, \mathrm{Fe}, \mathrm{Na}, \mathrm{Cu}, \mathrm{Zn}$ and moderate contribution (0.500 $<$ loadings $<0.700$ ) for $\mathrm{K}$ and $\mathrm{Ba}$. The first factor describing $29.4 \%$ of elemental content variation is mainly due to $\mathrm{Mg}$ and $\mathrm{Ca}$, but also to $\mathrm{K}$ and has been associated with soil carbonates, the main source of $\mathrm{Ca}$ and $\mathrm{Mg}$. The second factor (23.3\% variability) is due to $\mathrm{Al}$ and $\mathrm{Fe}$ and has been associated with the hydroxides contained in soil, the main source of these elements. 
The third factor ( $18.0 \%$ variability) is mainly due to $\mathrm{Na}$ but also to $\mathrm{Ba}$ which has a medium influence. Copper and $\mathrm{Zn}$, two essential microelements for plants, describe $12.7 \%$ of the characteristics variability of the plants under study.
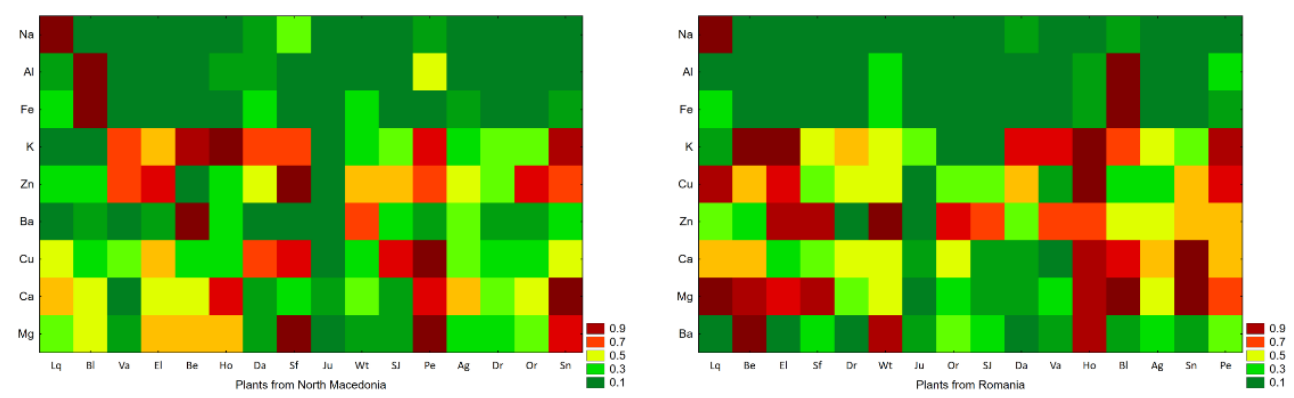

Figure 4. Two-way joining heat map revealing the elemental markers in medicinal plants from North Macedonia and Romania. The sample code of medicinal plants is presented in the experimental part, Table 5.

Table 3. Factor loadings after Varimax rotation of the first PCs with eigenvalue $>1.0$ reflecting the contribution of each variable in the characteristics of medicinal plants from North Macedonia. (Bold face loadings values $>0.700$, strong contribution; Italic loadings values $>0.500$, moderate contribution).

\begin{tabular}{|l|c|c|c|c|}
\hline Essential elements & Factor 1 & Factor 2 & Factor 3 & Factor 4 \\
\hline $\mathrm{Na}$ & 0.12 & 0.08 & $\mathbf{0 . 9 2}$ & -0.09 \\
\hline $\mathrm{K}$ & 0.62 & 0.31 & -0.43 & 0.37 \\
\hline $\mathrm{Mg}$ & $\mathbf{0 . 9 2}$ & -0.15 & 0.06 & 0.23 \\
\hline $\mathrm{Al}$ & 0.14 & $\mathbf{- 0 . 9 6}$ & -0.03 & -0.00 \\
\hline $\mathrm{Ca}$ & $\mathbf{0 . 9 3}$ & -0.05 & 0.05 & -0.04 \\
\hline $\mathrm{Fe}$ & -0.04 & $\mathbf{- 0 . 9 3}$ & 0.09 & -0.18 \\
\hline $\mathrm{Cu}$ & 0.17 & 0.07 & 0.14 & $\mathbf{0 . 8 2}$ \\
\hline $\mathrm{Zn}$ & 0.07 & 0.11 & -0.06 & $\mathbf{0 . 8 6}$ \\
\hline $\mathrm{Ba}$ & 0.12 & 0.18 & -0.66 & -0.41 \\
\hline Total variance (\%) & 29.4 & 23.3 & 18.0 & 12.7 \\
\hline Cumulative variance (\%) & 29.4 & 52.7 & 70.6 & 83.4 \\
\hline
\end{tabular}

The variability of medicinal plants in Romania (Table 4) is described in proportion of $70.0 \%$ by the first three factors, similar to $70.6 \%$ for plants from North Macedonia. Instead of this, there are differences between the contributions of elements on the characteristics variability. Thus, $33.1 \%$ is 
due to $\mathrm{Al}$ and $\mathrm{Fe}$ variability associated with the hydroxides contained soil. $\mathrm{A}$ variability of $20.3 \%$ is due to $\mathrm{Ba}$ but also $\mathrm{Na}, \mathrm{K}$ and $\mathrm{Zn}$, and $16.5 \%$ is due to $\mathrm{Mg}, \mathrm{Cu}$ and $\mathrm{Na}$. In both countries the influence of macroelements in high concentration, as is for example $\mathrm{K}$, was not revealed by a single factor. A similar observation was revealed for $\mathrm{Na}$ in case of plants from Romania.

Table 4. Factor loadings after Varimax rotation of the first PCs with eigenvalue $>1.0$ reflecting the contribution of each variable in the characteristics of medicinal plants from Romania. (Bold face loadings values $>0.700$, strong contribution; Italic loadings values $>0.500$, moderate contribution).

\begin{tabular}{|l|c|c|c|}
\hline Essential elements & Factor 1 & Factor 2 & Factor 3 \\
\hline $\mathrm{Na}$ & 0.02 & -0.65 & 0.57 \\
\hline $\mathrm{K}$ & 0.05 & 0.64 & 0.31 \\
\hline $\mathrm{Mg}$ & 0.30 & 0.10 & 0.81 \\
\hline $\mathrm{Al}$ & $\mathbf{0 . 9 8}$ & 0.09 & 0.09 \\
\hline $\mathrm{Ca}$ & 0.38 & 0.13 & 0.66 \\
\hline $\mathrm{Fe}$ & $\mathbf{0 . 9 7}$ & -0.04 & 0.14 \\
\hline $\mathrm{Cu}$ & -0.17 & 0.25 & 0.85 \\
\hline $\mathrm{Zn}$ & 0.05 & 0.56 & 0.00 \\
\hline $\mathrm{Ba}$ & -0.03 & $\mathbf{0 . 7 3}$ & 0.26 \\
\hline Total variance (\%) & 33.1 & 20.3 & 16.5 \\
\hline Cumulative variance (\%) & 33.1 & 53.4 & 70.0 \\
\hline
\end{tabular}

The differences between the factors variability for plants in two countries could be explained by differences between the soils on which they grew, namely a mountainous calcareous soil with higher carbonate content in North Macedonia, and one dominated by Fe and Al hydroxides in Romania. It would also explain the differences between plant varieties in these two countries.

\section{CONCLUSIONS}

The existence of a regional pattern of medicinal plants originating in North Macedonia and Romania has been demonstrated based on the macroelements and microelements content. Among the studied elements, the content of $\mathrm{K}, \mathrm{Ca}, \mathrm{Mg}, \mathrm{Al}$ and Fe can be considered as a marker parameter for medicinal plants. Medicinal plants such as blackberry and peppermint have been found to bio-accumulate the $\mathrm{Al}$ and $\mathrm{Fe}$. The content of $\mathrm{Na}, \mathrm{Al}$, Fe and $\mathrm{Ba}$ showed an asymmetric distribution while that of $\mathrm{K}, \mathrm{Ca}$ and $\mathrm{Zn}$ showed a symmetric distribution for plants in both countries. Some elements such as Mg showed a symmetric distribution only in plants from Romania. In general, a significant correlation was observed between elements with asymmetric distribution. The 
PCA analysis showed that the first four factors and the first three factors describe over $83.4 \%$ for North Macedonia and $70.0 \%$ for Romania with a strong influence from $\mathrm{Ca}, \mathrm{Mg}, \mathrm{Al}$ and $\mathrm{Fe}$ content. These were associated with the different soil composition of these two countries. The first factor in plants from North Macedonia was described by $\mathrm{Ca}$ and $\mathrm{Mg}$ in accordance with calcareous soil while the first factor in plants from Romania was described by $\mathrm{Al}$ and $\mathrm{Fe}$ in accordance with presence of hydroxides in the soil.

The PCA analysis showed that indeed the content of $\mathrm{Ca}, \mathrm{Mg}, \mathrm{Al}$ and Fe can be used for discriminating the medicinal plants from these two countries, which was also highlighted by the two-way joining Cluster Analysis. Obviously, the combination of elemental analysis and chemometric methods is an efficient approach in the study of regional pattern and characterization of the medicinal plants from different countries.

\section{EXPERIMENTAL SECTION}

\section{Reagents and standards}

Nitric acid $(69 \%)$ and hydrogen peroxide $(30 \%)$ of analytical reagent grade used for samples digestion were purchased from Merck (Darmstadt, Germany). Double distilled water was used through this study. An ICP multielement standard solution IV (CertiPUR IV, traceable to NIST, Merck, Darmstadt, Germany) contained 23 elements $\left(1000 \mathrm{mg} \mathrm{L}^{-1}\right)$ in diluted nitric acid was used for preparation of calibration standards in the range $0-1.0 \mathrm{mg} \mathrm{L}^{-1}$ element $(n=5)$ in $2 \%(v / v)$ diluted nitric acid, necessary for ICP -OES method. The calibration standards in the range $0-5.0 \mathrm{mg} \mathrm{L}^{-1} \mathrm{Na}$ and $\mathrm{K}(\mathrm{n}=6)$ in $2 \% \mathrm{v} / \mathrm{v}$ nitric acid were used in FAES method.

\section{Description of medicinal plants and samples}

The study was carried out on different vegetal parts (root, leave, flower, fruit and seeds) of 38 medicinal plants from North Macedonia and Romania (Table 5). The plants originated from North Macedonia were collected from the south-eastern part of the country, from three localities in the basin of the Osogovo Mountains. They were identified by determination key using the data from Matevski [15], a specimen being kept in the herbarium at the Department of Plant Production, Faculty of Agriculture, Goce Delcev University in Štip, North Macedonia. Samples of medicinal plants of Romania were purchased from a local specialized market. 
REGIONAL PATTERN AND CHARACTERISTICS OF ESSENTIAL ELEMENTS ...

Table 5. Description and provenience of investigated medicinal plants.

\begin{tabular}{|c|c|c|c|c|c|}
\hline No. & $\begin{array}{l}\text { Common } \\
\text { name }\end{array}$ & $\begin{array}{c}\text { Genus } \\
\text { (taxonomic rank) }\end{array}$ & Familly & $\begin{array}{l}\text { Part of } \\
\text { the plant }\end{array}$ & $\begin{array}{l}\text { Code of } \\
\text { sample }\end{array}$ \\
\hline \multirow[t]{3}{*}{1} & \multirow[t]{3}{*}{ Liquorice } & \multirow[t]{3}{*}{ Glycyrrhiza glabra L. } & \multirow[t]{3}{*}{ Fabaceae } & radix & $\mathrm{Lq}^{1 \mathrm{a}}$ \\
\hline & & & & radix & $\mathrm{Lq}^{1 \mathrm{~b}}$ \\
\hline & & & & radix & $\mathrm{Lq}^{2}$ \\
\hline \multirow[t]{2}{*}{2} & \multirow[t]{2}{*}{ Dandelion } & \multirow{2}{*}{$\begin{array}{l}\text { Taraxacum officinale } \\
\text { F.H.Wigg. }\end{array}$} & \multirow[t]{2}{*}{ Asteraceae } & radix & $\mathrm{Da}^{1}$ \\
\hline & & & & radix & $\mathrm{Da}^{2}$ \\
\hline \multirow[t]{2}{*}{3} & \multirow[t]{2}{*}{ Valerian } & \multirow[t]{2}{*}{ Valeriana officinalis $L$. } & \multirow[t]{2}{*}{ Caprifoliaceae } & radix & $\mathrm{Va}^{1}$ \\
\hline & & & & radix & $\mathrm{Va}^{2}$ \\
\hline \multirow[t]{3}{*}{4} & \multirow{3}{*}{$\begin{array}{l}\text { Sweet } \\
\text { fennel }\end{array}$} & \multirow{3}{*}{$\begin{array}{l}\text { Feniculum vulgare } \\
\text { var. dulcis Mill. }\end{array}$} & \multirow[t]{3}{*}{ Apiaceae } & fructus & $S f^{1 a}$ \\
\hline & & & & fructus & $S f^{1 b}$ \\
\hline & & & & fructus & $S w^{2}$ \\
\hline \multirow[t]{2}{*}{5} & \multirow[t]{2}{*}{ Dog rose } & \multirow[t]{2}{*}{ Rosa canina $L$. } & \multirow[t]{2}{*}{ Rosaceae } & fructus & $\mathrm{Dr}^{1}$ \\
\hline & & & & fructus & $\mathrm{Dr}^{2}$ \\
\hline \multirow[t]{2}{*}{6} & \multirow[t]{2}{*}{ Juniper } & \multirow{2}{*}{$\begin{array}{l}\text { Juniperus communis } \\
\text { L. }\end{array}$} & \multirow[t]{2}{*}{ Cupresaceae } & fructus & $\mathrm{Ju}^{1}$ \\
\hline & & & & fructus & $\mathrm{Ju}^{2}$ \\
\hline \multirow[t]{2}{*}{7} & \multirow[t]{2}{*}{ Bean } & \multirow[t]{2}{*}{ Phaseolus vulgaris $L$. } & Fabaceae & pericarpum & $\mathrm{Be}^{1}$ \\
\hline & & & & pericarpum & $\mathrm{Be}^{2}$ \\
\hline 8 & Elderberry & Sambucus nigra L. & Adoxaceae & flos & $\mathrm{El}^{1}$ \\
\hline & & & & flos & $\mathrm{El}^{2}$ \\
\hline 9 & Wild & Thymus serpyllum L. & Lamiaceae & herba & $W t^{1 a}$ \\
\hline & thyme & & & herba & $W t^{1 b}$ \\
\hline & & & & herba & $\mathrm{Wt}^{2}$ \\
\hline 10 & Oregano & Origanum vulgare $L$. & Lamiaceae & herba & $\mathrm{Or}^{1}$ \\
\hline & & & & herba & $O r^{2}$ \\
\hline 11 & Horsetail & Equisetum arvense $L$. & Equisetaceae & herba & $\mathrm{Ho}^{1}$ \\
\hline & & & & herba & $\mathrm{Ho}^{2}$ \\
\hline 12 & Peppermint & Mentha $x$ piperita $L$. & Lamiaceae & folium & $\mathrm{Pe}^{1}$ \\
\hline & & & & herba & $\mathrm{Pe}^{2 \mathrm{a}}$ \\
\hline & & & & folium & $\mathrm{Pe}^{2 \mathrm{~b}}$ \\
\hline 13 & Blackberry & Rubus fructicosus $L$. & Rosaceae & folium & $\mathrm{Bl}^{1}$ \\
\hline & & & & folium & $\left.\mathrm{B}\right|^{2}$ \\
\hline 14 & St.John's & Hypericum perforatum $L$ & Hypericaceae & herba & SJ1a \\
\hline & wort & & & herba & $S J^{1 b}$ \\
\hline & & & & herba & $\mathrm{SJ}^{2}$ \\
\hline 15 & Agrimony & Agrimonia eupatoria $L$. & Rosaceae & herba & $\mathrm{Ag}^{1}$ \\
\hline & & & & herba & $\mathrm{Ag}^{2}$ \\
\hline 16 & Stinging & Urtica dioica $L$. & Urticaceae & semen & $S n^{1 a}$ \\
\hline & nettle & & & folium & $S n^{1 b}$ \\
\hline & & & & herba & $\mathrm{Sn}^{2}$ \\
\hline
\end{tabular}

1 - Medicinal plants from North Macedonia; ${ }^{2}$ - Medicinal plants from Romania 


\section{Samples preparation}

Amounts of $0.50 \mathrm{~g}$ powdered vegetal material ( $\mathrm{n}=3$ paralel samples) weighed were overnight predigested in $10 \mathrm{~mL}$ of $\mathrm{HNO}_{3}(69 \%)$, and subjected to microwave-assisted digestion after $2 \mathrm{ml}$ of $\mathrm{H}_{2} \mathrm{O}_{2}(30 \%)$ addition. The microwave digestion program is provided in Supplementary material Table S2.

After cooling, the digest was transferred into $100 \mathrm{ml}$ volumetric flask, filtered and stored in polyethylene bottles at room temperature until analysis.

\section{Instrumentation}

The SPECTRO CIROSCCD spectrometer (Spectro, Kleve, Germany) was used for the ICP-OES measurements. Instrumental details and operating conditions are summarized in Supplementary material Table S3. Determination of elements was based on external calibration using a 5-point linear calibration curve over the range $0-1.0 \mathrm{mg} \mathrm{L}^{-1}$ element in $2 \% \mathrm{HNO}_{3}(\mathrm{v} / \mathrm{v})$. The emission signals as peak heights were measured using the best signal-to-noise ration SNR strategy for $48 \mathrm{~s}$ integration time.

The two points model approach was used for background correction. The most sensitive emission lines free of spectral interferences were selected.

For $\mathrm{Na}$ and $\mathrm{K}$ determination the FAES instrument using methane-air flame was interfaced with a low resolution microspectrometrer HR 4000 200$1100 \mathrm{~nm}$ spectral range Ocean Optix (Dunedin, USA). The flame was operated so that a stable burning was obtained. The emission spectrum was recorded using $500 \mathrm{~ms}$ integration time. The selected wavelengths were Na 588.995 $\mathrm{nm}$ and $\mathrm{K} 766.49 \mathrm{~nm}$.

A MW3S+ Berghof model closed-vessel microwave digestion system (Berghof, Germany) with temperature monitoring option up to $210{ }^{\circ} \mathrm{C}$ was used for sample mineralization.

\section{Analytical performance and methods validation}

The analytical performances of the ICP-OES and FAES methods were evaluated in terms of the limit of detection (LOD), limit of quantification (LOQ), precision and accuracy. LOD was calculated using the $(3 \sigma)$ criterion and parameters of the calibration curve [16].

$$
L O D=\frac{3 s_{b}}{m}
$$

where $\left(\mathrm{s}_{\mathrm{b}}\right)$ is the standard deviation of background assessed from 11 measurements of reagent blank $2 \% \mathrm{~V} / \mathrm{V} \mathrm{HNO}_{3}$, while $(\mathrm{m})$ the slope of the calibration curve. 
LOQ was considered as $3 \times$ LOD. Values of LOD and LOQ in solid sample were calculated taking into account the sample preparation protocol. Statistical evaluation of the linear calibration function was assessed according to SR ISO 8466-1 [17]. The parameters of the calibration curves (LODs and LOQs) for ICP-OES and FAES methods are presented in Supplementary material Table S4.

A good linearity of the calibration curves with determination coefficients in the range $0.9949-1.0000$ was obtained. The LODs were in the range 0.068 (Ba) - 8.471 $(\mathrm{Pb}) \mathrm{mg} \mathrm{kg}^{-1}$ while LOQs were in the range $0.205-25.413 \mathrm{mg} \mathrm{kg}^{-1}$ in ICP-OES (Table 1). The LODs in FAES were $10.27 \mathrm{mg} \mathrm{kg}^{-1}$ for $\mathrm{Na}$ and $0.051 \mathrm{mg} \mathrm{kg}^{-1}$ for K.

The ICP-OES and FAES methods were previously validated by analysing a several materials of vegetables and fruits providing recovery in the range $87-108 \%$ [18]. The relative expanded uncertainly $(k=2,95 \%)$ was in the range $9-25 \%$. The major contribution to combine standard uncertainty come from replicate analysis, fitting and standard preparation.

\section{Statistical analysis}

Two-way joining cluster analysis was used to reveal the elements significantly different in medicinal plants samples and to better explore variability in elemental composition on samples from North Macedonia and Romania. Two-way clustering is a common multivariate technique used to analyse complex data matrices and produces a heat map graph (two-way display of a data matrix) ordering cases and variables based on similarity patterns. The individual cells in the heat map are displayed as colored rectangles where the color of a cell is proportional to its position along a color gradient. The elements were shown as column variables of the data matrix while the variety medicinal plants were shown as rows.

The PCA with varimax rotation approach was used to maximize the variation expressed by the principal components (PCs). The varimax rotation algorithm rearrange the amount of variance among principal components, so each new factor has only few variables with significant contribution (large loadings) and many others with no significant contribution (low loadings). In this study only PCs with eigenvalue $>1$ were retained for varimax rotation method.

Correlations and multivariate statistical analyses were performed using the Software Package Statistica 8.0 (StatSoft inc. 1984-2007, USA).

\section{ACKNOWLEDGMENTS}

This work was supported by a grant of Ministry of Research and Innovation, Romania, Project number 33PFE/2018, within PNCDI III. 


\section{REFERENCES}

1. R.P. Chouldhry; R. Acharyu; A.G.C. Nair; A.V.R. Reddy; A.N. Garg; J. Radioanal. Nucl. Chem. 2004,120, 85-93.

2. E.I. Obianjunwa; C. Adeleke; O. Adebajo; O. Omubuwajo; J. Radioanal. Nucl. Chemistry; 2004, 252, 473-476.

3. A. Łozak; K. Sołtyk; M. Kiljan; Z. Fijałek; P. Ostapczuk; Pol. J. Nutr. Sci. 2012, 62, 97-102.

4. S.A. Sattar; B.S. Reddy; V.K. Rao; A.S. Pradeep; G.J.N. Raju; K. Ramanarayana; P.V.M. Rao; S.B. Reddy; J. Radioanal. Nucl. Chem. 2012, 294, 337-341.

5. H. Matsuura; A. Hokura; F. Katsuki; A. Itoh; H. Haraguchi; Anal. Sci. 2001,17, 391-398.

6. V.A. Aletor; O.A. Omodara; Anim. Feed Sci. Technol. 1994, 46, 343-348.

7. A.M. Ebrahim; M.H. Eltayeb; H. Khalid; H. Mohamed; W. Abdalla; P. Grill; B. Michalke; J. Nat. Med. 2012, 66, 671-679.

8. S.S. Ranđelović; D.A. Kostić; A.R. Zarubica; S.S. Mitić; M.N. Mitić; Hem. Ind. 2013 , 67, 585-591.

9. (2007) WHO (World Health Organization) guidelines for assessing quality of herbal medicines with reference to contaminants and residues. Geneva 2007.

10. (2011) WHO (World Health Organization) The world traditional medicines situation. in Traditional Medicines: Global Situation, Issues and Challenges. WHO, Geneva, Switzerland 3: 1-14.

11. P.S.C. Silva; L.S. Francisconi; R.D.M.R. Gonçalve, J. Braz. Chem. Soc., 2016, 27, 2273-2289.

12. D. Casoni; M. Ponta; M.-N. Bibica; I.-V. Lazar; T. Frentiu; Rev. Roum. Chim., 2020, 65, 573-578.

13. W. Kathe; S. Honnef; A. Heym; Medicinal and Aromatic Plants in Albania, BosniaHerzegovina, Bulgaria, Croatia and Romania. Geography, Social and Political Structure, Biodiversity and Nature Conservation, Wild-Harvesting and Cultivation of MAPs, Bundesamt für Naturschutz, Bonn, 2003, pp. 30-34.

14. H.M. Sabo; Res. J. Agric. Sci. 2012, 44, 226-232.

15. V. Matevski; Flora of the Republic of Macedonia, 1st Edition, Macedonian Academy of Science and Arts, Skopje, 2010.

16. J.N. Miller; J.C. Miller; Statistics and chemometrics for analytical chemistry, 4th Edition, Pearson Education Ltd., Edinburgh Gate, England, 2000.

17. SR ISO 8466-1:1999. Water quality. Calibration and evaluation of analytical methods and estimation of performance characteristics. Part I. Statistical evaluation of the linear calibration function

18. E. Covaci; M. Senila; M. Ponta; T. Frentiu; Rev. Roum. Chim., 2020, 65, 735-745. 